\title{
A Method for Determination of Ammonia in Air using Oxalic Acid-Impregnated Cellulose Filters and Fluorimetric Detection
}

\author{
Erika P. Felix ${ }^{a}$ and Arnaldo A. Cardoso ${ }^{*, b}$ \\ ${ }^{a}$ Departamento de Química e Biologia, Universidade Tecnológica Federal do Paraná, \\ Av. Sete de Setembro 3165, Rebouças, 80230-901 Curitiba-PR, Brazil \\ ${ }^{b}$ Instituto de Química, Universidade Estadual Paulista, CP 355, 14800-900 Araraquara-SP, Brazil
}

\begin{abstract}
Um método fluorimétrico foi adaptado para determinação de amônia no ar ambiente. A coleta da amostra foi feita em filtros de celulose impregnados com ácido oxálico, seguida pela solubilização do íon amônio, adição dos reagentes e determinação fluorimétrica. Alguns parâmetros analíticos importantes foram avaliados, tais como tempo e vazão de amostragem. Formaldeído, dietilamina e sulfeto de hidrogênio não interferiram no método. A curva analítica apresentou linearidade até pelo menos 34 ppbv, em vazão e tempo de amostragem respectivos de $0,3 \mathrm{~L} \mathrm{~min}^{-1}$ e $20 \mathrm{~min}$. Nestas condições, o limite de detecção alcançado foi de 3 ppbv. O método proposto aqui apresentou resultados similares ao método colorimétrico do indofenol, porém necessitou de um tempo de amostragem menor. Mostrou ser de fácil aplicação, sendo útil para medir baixas concentrações de amônia e possíveis flutuações na sua concentração em intervalos de tempo curtos, como 20 min.
\end{abstract}

A fluorimetric method was developed for the determination of ammonia in ambient air. Samples were collected using cellulose filters impregnated with oxalic acid, followed by solubilization of the ammonium ion, addition of reagents and fluorimetric detection. Important analytical parameters that were evaluated included sampling time and flow rate. Formaldehyde, diethylamine and hydrogen sulfide did not interfere in the method. The analytical curve was linear up to at least $34 \mathrm{ppbv}$ of ammonia, using a sample flow rate of $0.3 \mathrm{~L} \mathrm{~min}^{-1}$ and a sampling time of $20 \mathrm{~min}$. The limit of detection achieved under these conditions was 3 ppbv. The proposed method offers advantages compared to the indophenol colorimetric method, especially the ability to use a shorter sampling time. The method proved to be easy to apply, and should be useful in applications where measurements of low concentrations of ammonia are required, or where there are rapid fluctuations in ammonia concentrations over periods as short as $20 \mathrm{~min}$.

Keywords: gaseous ammonia, acid-impregnated filter, fluorimetric detection, $o$-phthaldialdehyde, isoindole

\section{Introduction}

Ammonia $\left(\mathrm{NH}_{3}\right)$ is found naturally in ambient air, as well as emitted from anthropogenic sources, and plays a role in atmospheric chemistry. It has many sources, including agriculture, fossil fuel combustion, industrial emissions and biochemical processes in natural soils. ${ }^{1-4}$ Food production is a significant source of ammonia, with emissions occurring due to application of fertilizer or manure to soils and volatilization from animal waste. ${ }^{5-7}$ Close to the source, $\mathrm{NH}_{3}$ is deposited onto vegetation, soil and water, and consequently may both modify acidity

*e-mail: acardoso@ iq.unesp.br and increase the availability of nitrogen, which can lead to eutrophication of surface waters. ${ }^{8} \mathrm{NH}_{3}$ is considered an important pollutant due to its role as a precursor in fine particulate matter formation, in the formation of the greenhouse gas nitrous oxide $\left(\mathrm{N}_{2} \mathrm{O}\right)$, and in the nitrogen balance of ecosystems. ${ }^{9-11}$ The fine particulates formed in the atmosphere due to acid-base reactions of ammonia with acidic sulfur- and nitrogen-containing gases are responsible for long-range transport of nitrogen and sulfur. ${ }^{12,13}$ In many regions, a large fraction of airborne fine particulate matter consists of ammonium salts formed during neutralization of atmospheric acid gases. The incorporation of ammonia in the aqueous phase of the aerosol enhances the solubility of $\mathrm{SO}_{2}$, and increases its oxidation rate. ${ }^{12}$ High levels of 


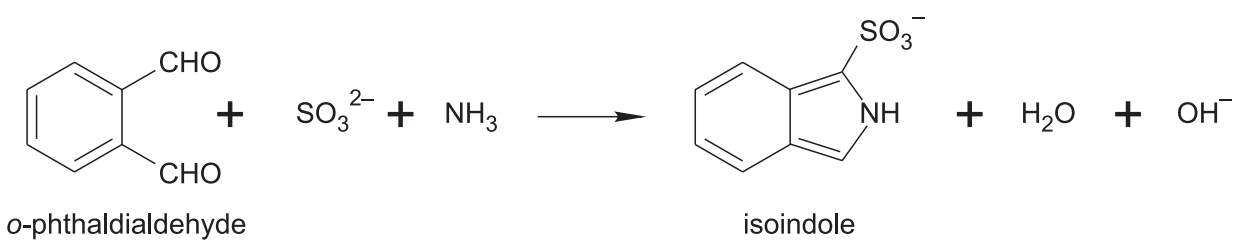

Figure 1. Schematic of the reaction between ammonia and $o$-phthaldialdehyde in the presence of sulfite.

ammonia are of concern in large-scale animal production, for reasons of hygiene and odor, since adequate indoor air quality in buildings housing animals is essential for the health of agricultural workers and livestock. ${ }^{14}$

Concentrations of ammonia in the lower troposphere are usually low. For example, in central São Paulo State levels of ammonia in the range 0.5-3.4 ppb have been found even close to sources such as agricultural areas and biomass burning. ${ }^{15}$ This can be explained by the reactivity and solubility of ammonia, as well as its fairly rapid dry deposition close to emission sources, which results in a short atmospheric lifetime. ${ }^{16}$

Evaluation of the emission rates, transport and fate of ammonia requires information concerning its atmospheric concentration. Spectroscopic methods such as photofragmentation laser-induced fluorescence, differential optical absorption spectroscopy (DOAS), Fourier transform infrared (FTIR) spectroscopy are expensive, require a dedicated operator, and are not suitable for routine application..$^{1,17}$ The low atmospheric concentration of ammonia limits the applicability of many chemical measurement methods, which normally require a preconcentration step. Procedures involving absorption using acidic solutions, ${ }^{18}$ coated-wall denuders ${ }^{19}$ and acid-impregnated filters ${ }^{20,21}$ have been reported in the literature for the collection of ammonia. Although methods using acid-impregnated filters generally require a long sampling time, the use of filters is highly practical for field measurements. After extraction into aqueous solution, detection of dissolved ammonium ions has been performed by photometry ${ }^{22}$ and ion chromatography. ${ }^{23}$

An attraction of fluorescence-based techniques is their sensitivity, which is usually one to three orders of magnitude better than that of absorbance-based systems. A variety of fluorescence and chemiluminescence methods have been proposed as a result. ${ }^{24-26}$ In the 1970 s, Roth described a fluorescence reaction for ammonia with $o$-phthaldialdehyde and 2-mercaptoethanol. ${ }^{27} \mathrm{Jacobs}^{25}$ suggested that sulfite offered advantages as a reducing agent, compared to 2-mercaptoethanol, and Genfa and Dasgupta ${ }^{28}$ confirmed that the spectral characteristics of the OPA-sulfite reaction product are considerably more attractive for fluorimetric detection than the corresponding product obtained using 2-mercaptoethanol. The use of the OPA-sulfite reaction for the determination of ammonia has mainly focused on its measurement in water. ${ }^{29,30}$ Westra et al..$^{31}$ employed a fluorimetric method for determination of ammonia in air and breath, although the collection of gaseous $\mathrm{NH}_{3}$ into a nitrogen-cooled sample trap, equipped with Teflon inlet and outlet valves and a pressure sensor, limits its use in the field. Groves et al. ${ }^{32}$ proposed the collection of ammonia in a sorbent tube containing $100 \mathrm{mg}$ of acid-treated silica gel.

In this paper, we propose the use of oxalic acidimpregnated cellulose filters to collect gaseous ammonia, with analysis using fluorescence based on chemical reaction of ammonia with $o$-phthaldialdehyde and sodium sulfite (Figure 1). The advantages of this approach are the use of a sampling device that is low cost, easy to prepare and readily deployed for field measurements, together with a highly sensitive analytical technique.

\section{Experimental}

\section{Ammonia-free water}

Ammonia is highly soluble in water, so that it is difficult to store ammonia-free water in the laboratory without potential contamination from the ammonia present in indoor air. In the present work, ammonia-free water was prepared daily by further purifying distilled water by reverse osmosis. This water was used to prepare all solutions employed during the development of the proposed method.

\section{Reagent solutions}

Six solutions of $o$-phthaldialdehyde (Aldrich) were prepared, at concentrations ranging from 0.0125 to $0.05 \mathrm{~mol} \mathrm{~L}^{-1}$. Portions of $o$-phthaldialdehyde were dissolved in $2.5 \mathrm{~mL}$ of methanol, followed by addition of water to make up to a final volume of $10 \mathrm{~mL}$. These solutions were stored refrigerated for up to 1 week. Four sodium sulfite (Merck) solutions were prepared by dissolving 0.0126 to $0.0630 \mathrm{~g}$ of the salt in phosphate buffer, made up to a final volume of $10 \mathrm{~mL}$. The phosphate buffer was prepared by dissolution of $6.7 \mathrm{~g}$ of $\mathrm{Na}_{2} \mathrm{HPO}_{4}$ in $200 \mathrm{~mL}$ of water, adjusting the $\mathrm{pH}$ to 11 with $2 \mathrm{~mol} \mathrm{~L}^{-1} \mathrm{NaOH}$, and diluting to $250 \mathrm{~mL}$. These solutions were prepared daily. The coating 
solution was prepared by dissolving $50 \mathrm{~g}$ of oxalic acid (Mallinckrodt) and $20 \mathrm{~mL}$ of glycerol (Merck) in water, with the volume made up to $1 \mathrm{~L}$.

\section{Preparation of sampling filters}

Whatman N. 41 cellulose filters were cut into $15 \mathrm{~mm}$ diameter circles. Any ammonium contamination was then removed by soaking the filter circles in deionized water for two days, changing the water four times daily. The filters were then immersed in oxalic acid solution for $4 \mathrm{~h}$, and rinsed with water. Finally, the filter circles were immersed overnight in a $5 \%(\mathrm{~m} / \mathrm{v})$ oxalic acid/glycerol solution, and dried in a desiccator for at least $24 \mathrm{~h}$. The dry filters were wrapped in oxalic acid-impregnated filter paper, and stored in a refrigerator prior to use.

\section{Sampler arrangement}

The sampler arrangement used to house the impregnated filters was constructed as previously described by Felix et al. ${ }^{33}$ The sampler was adapted from a $12 \mathrm{~mL}$ hypodermic syringe, from which part of the body had been removed (Figure 2). The impregnated filter was placed at the bottom of the sampler, and a plastic ferrule was used to seal the air inlet before and after sampling.

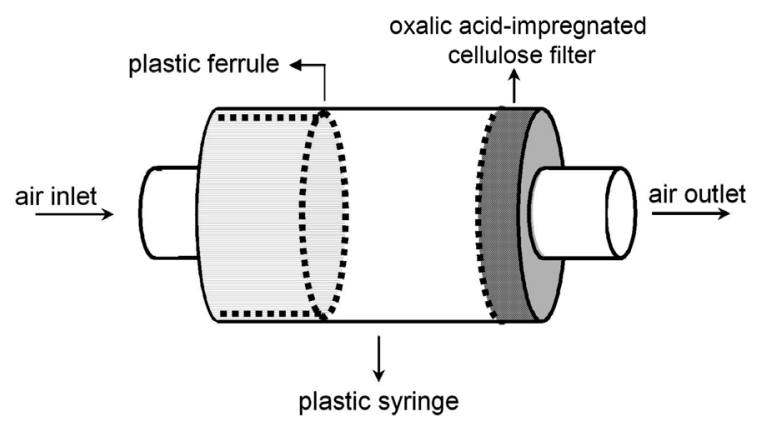

Figure 2. Sketch of the components of the ammonia sampler.

\section{Generation of ammonia standard gas mixture}

The equipment used for ammonia standard gas generation is illustrated in Figure 3, and followed the same procedure described previously. ${ }^{34}$ An ammonia permeation tube device (VICI Metronics, Santa Clara), certified to release $\mathrm{NH}_{3}$ at a rate of $22.9 \mathrm{ng} \mathrm{min}-1$ (at $30^{\circ} \mathrm{C}$ ), was placed inside the permeation chamber and maintained at a constant temperature of $30.0 \pm 0.1{ }^{\circ} \mathrm{C}$. Air was purified by passage through three sequential columns $(20 \mathrm{~mm} \times 40 \mathrm{~cm})$ containing silica gel (A1), activated carbon (A2) and oxalic acid solution supported on silica gel (A3). One portion of the flow of pure air was directed to the permeation chamber, at $1.0 \mathrm{~L} \mathrm{~min}^{-1}$. This primary stream (FC2) could be diluted with a second pure air stream (FC3). A desired portion of the resultant total flow was sampled (FC5), and the remainder of the standard gas was discarded with the aid of a vacuum pump (P) controlled by a needle valve (NV3).

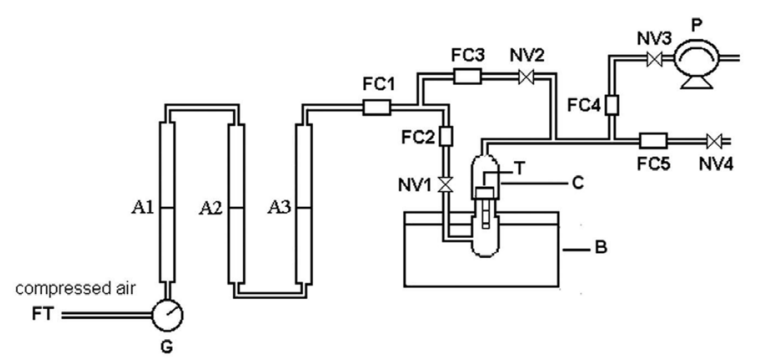

Figure 3. Ammonia gas generation system: FT, total flow rate; $\mathrm{G}$, pressure gauge; A1-3, sequential columns for air purification; FC1-5, flowmeters; NV1-4, needle valves; C, permeation chamber; T, permeation tube; B, thermostatic bath; $P$, vacuum pump.

\section{Experimental protocol}

The following experimental protocol was used: (i) a filter impregnated with oxalic acid was loaded into the sampler; (ii) after sampling, the filter was placed inside a hypodermic syringe $(12 \mathrm{~mL})$ without the piston. The filter was shaken with about $3.0 \mathrm{~mL}$ of water. This solution was forced out into a $5.0 \mathrm{~mL}$ volumetric flask with the aid of the piston; (iii) $1.0 \mathrm{~mL}$ of $o$-phthaldialdehyde solution was added, followed by $1.0 \mathrm{~mL}$ of sodium sulfite solution, with the final volume made up to $5.0 \mathrm{~mL}$; (iv) after formation of the fluorescent product, the fluorescence of the solution was measured using a Shimadzu RF-1501 spectrofluorimeter $\left(\lambda_{\mathrm{ex}}=360 \mathrm{~nm}\right.$ and $\lambda_{\mathrm{em}}=425 \mathrm{~nm}$ ), with an optical length of $10 \mathrm{~mm}$.

Measurements of blank were made following the same procedure of the samples, but without exposure of the filter system to generate ammonia. The difference signal between sample and blank was considered as analytical signal.

\section{Results and Discussion}

\section{Optimum fluorescence}

Initially, experiments were performed using three different sampling times (0,30 and $60 \mathrm{~min})$ and an ammonia concentration of $34 \mathrm{ppbv}$, at a sampling flow rate of $0.4 \mathrm{~L} \mathrm{~min}^{-1}$ and reaction time of $30 \mathrm{~min}$. After sampling, the ammonium collected in the filters was extracted with deionized water, and the reagents added as described previously. The excitation and emission spectra of the fluorescent product were investigated using the 
spectrofluorimeter, and the results of the scans (Figure 4) showed that the greatest fluorescence response occurred at an excitation wavelength of $360 \mathrm{~nm}$ and an emission wavelength of $425 \mathrm{~nm}$.

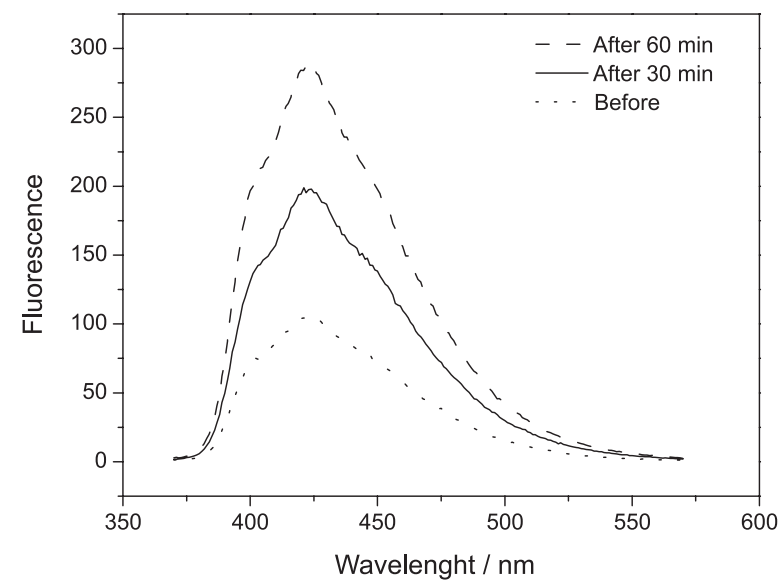

Figure 4. Fluorescence spectra of the product of the reaction between ammonia ( $34 \mathrm{ppbv}$ ), $o$-phthaldialdehyde and sulfite during three stages: before sampling of ammonia, after $30 \mathrm{~min}$ of sampling, and after $60 \mathrm{~min}$ of sampling. Excitation wavelength set at $360 \mathrm{~nm}$, sampling flow rate of $0.4 \mathrm{~L} \mathrm{~min}^{-1}$ and reaction time of $30 \mathrm{~min}$.

Influence of o-phthaldialdehyde and sodium sulfite concentrations

The influences of $o$-phthaldialdehyde and sodium sulfite concentrations on the fluorescent product were studied using an ammonia concentration of $34 \mathrm{ppbv}$, a sampling time of $20 \mathrm{~min}$, sampling flow rate of $0.3 \mathrm{~L} \mathrm{~min}^{-1}$ and reaction time of $15 \mathrm{~min}$ (Figure 5). The best

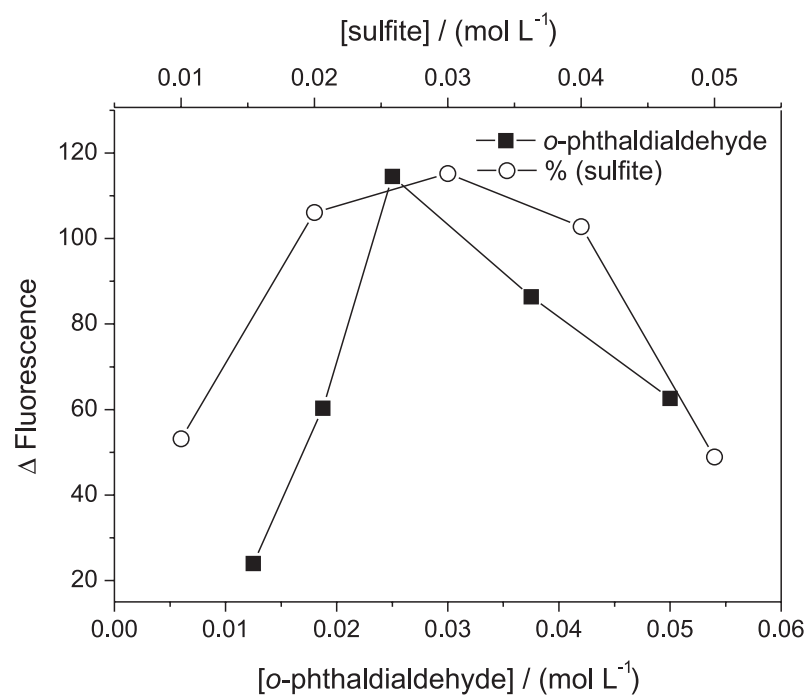

Figure 5. Analytical signals obtained as a function of $o$-phthaldialdehyde and sulfite concentrations. Conc. $\mathrm{NH}_{3}=34$ ppbv, sampling flow rate $=0.3 \mathrm{~L} \mathrm{~min}^{-1}$, sampling time $=20 \mathrm{~min}$, reaction time $=15 \mathrm{~min}$. Excitation $\left(\lambda_{\text {exc }}\right)$ and emission $\left(\lambda_{\mathrm{em}}\right)$ wavelengths of $360 \mathrm{~nm}$ and $425 \mathrm{~nm}$, respectively. analytical signal was obtained with an $o$-phthaldialdehyde concentration of $0.025 \mathrm{~mol} \mathrm{~L}^{-1}$ and a sulfite concentration between 0.02 and $0.04 \mathrm{~mol} \mathrm{~L}^{-1}$. In subsequent experiments, the concentrations of $o$-phthaldialdehyde and sodium sulfite used in all procedures were $0.025 \mathrm{~mol} \mathrm{~L}^{-1}$ and $0.03 \mathrm{~mol} \mathrm{~L}^{-1}$, respectively.

\section{Effect of sampling time}

The duration of sampling is an important parameter in all atmospheric analyses that include a preconcentration step. The influence of sampling time was investigated using a sampling flow rate of $0.3 \mathrm{~L} \mathrm{~min}^{-1}$ and an ammonia concentration of $34 \mathrm{ppbv}$. The results obtained are shown in Figure 6.

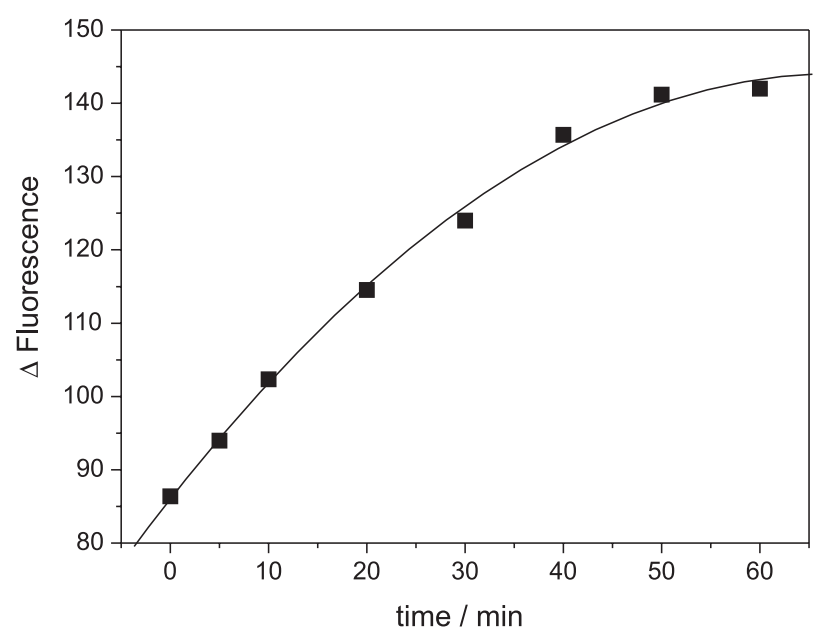

Figure 6. Analytical signal as a function of sampling time. Conc. $\mathrm{NH}_{3}=34 \mathrm{ppbv}$, sampling flow rate $=0.3 \mathrm{~L} \mathrm{~min}^{-1}$, reaction time $=15 \mathrm{~min}$, $\lambda_{\text {exc }}=360 \mathrm{~nm}, \lambda_{\mathrm{em}}=425 \mathrm{~nm}$.

The analytical signal initially increased linearly with increasing sampling time, before reaching a maximum. The data points could be fitted by a second-degree polynomial as follows,

$\Delta S=86.04+1.703 t-0.01254 t^{2} \quad R=0.9970$

where $\Delta \mathrm{S}$ is the fluorescence signal and $\mathrm{t}$ is the sampling time in minutes. If the impregnated filter collected ammonia with no change in efficiency with time, the points would be expected to be connected by a straight line. However, linearity was only observed for short sampling times (ca. $20 \mathrm{~min}$ ), when the quadratic term of the equation was insignificant compared with the other terms. In accordance with equation 1, a sampling time of 20 min was selected, which ensured good linearity (with a maximum deviation of only 4\%) between the amount of ammonia and the fluorescence signal. 


\section{Effect of sampling flow rate}

For the same sampling time, an increased flow means that a greater number of molecules reach the impregnated filter, although increased breakthrough at higher flow rates results in the samplers being most efficient within a fairly narrow flow rate range. Here, $34 \mathrm{ppbv}$ of ammonia was passed through the impregnated filter for $20 \mathrm{~min}$, and the gas flow rate was varied from 0.1 to $0.5 \mathrm{~L} \mathrm{~min}^{-1}$. The results are shown in Table 1.

Table 1. Analytical signal as a function of sampling flow rate. Conc. $\mathrm{NH}_{3}=34$ ppbv, sampling and reaction times of 20 and $15 \mathrm{~min}$, respectively. $\lambda_{\mathrm{exc}}=360 \mathrm{~nm}, \lambda_{\mathrm{em}}=425 \mathrm{~nm}$.

\begin{tabular}{cc}
\hline Sampling flow rate / $\left(\mathrm{L} \mathrm{min}^{-1}\right)$ & $\Delta$ Fluorescence \\
\hline 0.1 & 34.06 \\
0.2 & 92.14 \\
0.3 & 114.53 \\
0.4 & 115.97 \\
0.5 & 114.26 \\
\hline
\end{tabular}

The fluorescence signal increased with increasing sampling rate, reaching a maximum at $0.3 \mathrm{~L} \mathrm{~min}^{-1}$, after which no further improvement in the signal was observed. This was the sampling flow rate chosen for subsequent experiments.

\section{Interferences}

Possible interferences in the analytical signal due to the presence of other reactive molecules were investigated using the three gases diethylamine, formaldehyde and hydrogen sulfide. Air/ammonia standard gas mixtures were contaminated with these gases emitted from permeation tubes (VICI Metronics, Santa Clara, CA). The results showed that no interferences occurred, even when the gases were present at levels three times higher than the ammonia concentration.

The determination of $\mathrm{N}$ (-III) by reaction with $o$-phthaldialdehyde can be used for amines and amino acids, as well as ammonia. ${ }^{25}$ However, in the present application the use of oxalic acid as the reagent for impregnation of filters to collect ammonia appears to be advantageous, since oxalic acid is shown to be highly inefficient for collection of diethylamine (and, by inference, other amines).

\section{Sensitivity and limits of detection}

The response of the method was investigated using different ammonia concentrations. Here, the sampling flow rate was $0.3 \mathrm{~L} \mathrm{~min}^{-1}$, the sampling time was $20 \mathrm{~min}$ and the reaction time was $15 \mathrm{~min}$. The ammonia concentrations ranged from 0 to $34 \mathrm{ppbv}$ (concentrations exceeding this range are not usually encountered in the outdoor atmosphere).,21 Three samples were collected at each concentration, and the averages calculated. The following linear relationship was obtained,

$\Delta \mathrm{S}=(71.65 \pm 0.25)+(1.30 \pm 0.02)\left[\mathrm{NH}_{3}\right] \quad \mathrm{R}=0.9997$

where $\Delta \mathrm{S}$ represents the fluorescence analytical signal, and $\left[\mathrm{NH}_{3}\right]$ the ammonia concentration (in ppbv). Although the upper limit of linearity was not reached, the analytical signal increased linearly up to at least $34 \mathrm{ppbv}$ of ammonia. The detection limit, considered to be three times the standard deviation of the blank signal, divided by the straight-line angular coefficient, was better than 3 ppbv. This limit depends on the ratio between the magnitude of the analytical signal and that of the fluctuations of the blank signal, and is usually higher because of contamination arising from the presence of ammonia in the environment. The major source of contamination in the laboratory is frequently the operator; the ammonia concentration in expired air can be as high as one hundred parts per billion. ${ }^{35}$ Limits of detection can be improved by using a longer sampling time, which increases the analytical signal, albeit at the expense of sampling frequency. Nonetheless, the results obtained here demonstrate that environmental ammonia contamination can be successfully controlled and avoided. The relative standard deviation (RSD) for 10 replicates of 34 ppbv of ammonia determination was $5 \%$, indicating a very reproducible response.

\section{Conclusions}

The use of filters treated with oxalic acid, combined with an analytical technique based on the detection of fluorescence after reaction of ammonium with $o$-phthaldialdehyde in the presence of sodium sulfite, provides a sensitive method for the measurement of atmospheric ammonia. The analytical protocol employed is simple, and the system is compact, easily constructed and of low cost. The sensitivity of the method can be readily adjusted (upwards or downwards) by altering the sampling time, enabling deployment in environments with widely differing ammonia levels. Additionally, other solid supports may be tested and used in the development of new samplers.

Preliminary measurements were made in outdoor air, using the method developed here and the indophenol method (colorimetric determination at $600 \mathrm{~nm}$ ). ${ }^{1}$ The results were similar and the outdoor ammonia concentrations varied 
from 0.5 to 5 ppbv during the daytime, with higher values at evening ( 8 ppbv). However, the indophenol method requires sampling times longer than $6 \mathrm{~h}$ in environments where the concentration of ammonia is only a few ppbv. The new procedure described here therefore affords the opportunity to readily obtain an improved understanding of the atmospheric ammonia cycle, involving both emission and consumption of the gas, during much shorter periods of an hour or less.

\section{Acknowledgments}

We gratefully acknowledge the financial support of CNPq (Brazilian National Council for Scientific and Technological Development) and FAPESP (State of São Paulo Research Foundation).

\section{References}

1. Felix, E. P.; Cardoso, A. A.; Quim. Nova 2004, 27, 123.

2. Da Rocha, G. O.; Allen, A.; Cardoso, A. A.; Environ. Sci. Technol. 2005, 39, 5293.

3. Livingston, C.; Rieger, P.; Winer, A.; Atmos. Environ. 2009, 43, 3326.

4. Rumburg, B.; Mount, G. H.; Filipy, J.; Lamb, B.; Westberg, H.; Yonge, D.; Kincaid, R.; Johnson, K.; Atmos. Environ. 2008, 42, 3364.

5. Zhang, Y.; Luan, S.; Chen, L.; Shao, M.; J. Environ. Manage. 2011, 92,480 .

6. Sommer, S. G.; Ostergard, H. S.; Lofstrom, P.; Andersen, H. V.; Jensen, L. S.; Atmos. Environ. 2009, 43, 915.

7. Harper, L. A.; Flesch, T. K.; Powell, J. M.; Coblentz, W. K.; Jokela, W. E.; Martin, N. P.; J. Dairy Sci. 2009, 92, 2326.

8. Baum, K. A.; Ham, J. M.; Atmos. Environ. 2009, 43, 1753.

9. Wu, S-Y.; Hu, J-L.; Zhang, Y.; Aneja, V. P.; Atmos. Environ. 2008, 42, 3437.

10. Plessow, K.; Spindler, G.; Zimmermann, F.; Matschullat, J.; Atmos. Environ. 2005, 39, 6995.

11. Allen, A. G.; Cardoso, A. A.; Wiatr A. G.; Machado, C. M. D.; Paterlini, W. C.; Baker, J.; J. Braz. Chem. Soc. 2010, 21, 87.

12. Tursic, J.; Berner, A.; Podkrajsek, B.; Grgic, I.; Atmos. Environ. 2004, 38, 2789.
13. Renner, E.; Wolke, R.; Atmos. Environ. 2010, 44, 1904.

14. Ni, J. Q.; Hendriks, J.; Vinckier, C.; Coenegrachts, J.; Environ. Int. 2000, 26, 97.

15. Machado, C. M. D.; Allen, A. G.; Cardoso, A. A.; Environ. Sci. Technol. 2008, 42, 381.

16. Theobald, M. R.; Bealey, W. J.; Tang, Y. S.; Vallejo, A.; Sutton, M. A.; Sci. Total Environ. 2009, 407, 6024.

17. Parrish, D. D.; Fehsenfeld, F. C.; Atmos. Environ. 2000, 34, 1921.

18. Lodge Jr., J. P.; Methods of Air Sampling and Analysis, $3^{\text {rd }}$ ed., Lewis Publishers: Michigan, 1989.

19. Luo, Y.; Al-Othman, R.; Christian, G. D.; Ruzicka, J.; Talanta 1995, 42, 1545.

20. Kasper, A.; Puxbaum, H.; Anal. Chim. Acta 1998, 32, 3925.

21. Ugucione, C.; Felix, E. P.; Rocha, G. O.; Cardoso, A. A.; Eclét. Quim. 2002, 27, 103.

22. Searle, P. L.; Analyst 1984, 109, 549.

23. Perrino, C.; Gherardi, M.; Atmos. Environ. 1999, 33, 4579.

24. Feigl, F.; Spot Tests in Inorganic Analysis, Elsevier: Amsterdam, 1972.

25. Jacobs, W. A.; J. Chromatogr. 1987, 392, 435.

26. Li, J. Z.; Dasgupta, P. K.; Anal. Chim. Acta 1999, 398, 33.

27. Roth, M.; Anal. Chem. 1971, 43, 880.

28. Genfa, Z.; Dasgupta, P. K.; Anal. Chem. 1989, 61, 408.

29. Kérouel, R.; Aminot, A.; Mar. Chem. 1997, 57, 265.

30. Aminot, A.; Kérouel, R.; Birot, D.; Water Res. 2001, 35, 1777.

31. Westra, H. G.; Van Doorn, J. E.; Tigchelaar, R. G.; Berden, J. A.; Anal. Biochem. 2001, 296, 225.

32. Groves, W. A.; Agarwal, D.; Chandra, M. J.; Reynolds, S. J.; J. Environ. Monit. 2005, 7, 163.

33. Felix, E. P.; de Souza, K. A. D.; Dias, C. M.; Cardoso, A. A.; J. AOAC Int. 2006, 89, 480 .

34. Felix, E. P.; Cardoso, A. A.; Instrum. Sci. Technol. 2003, 31, 283.

35. Ugucione, C.; Cardoso, A. A.; Anal. Bioanal. Chem. 2007, 389, 1647.

Submitted: March 3, 2011

Published online: November 3, 2011

FAPESP has sponsored the publication of this article. 